\title{
Ultrasound assisted synthesis of enaminones using Nickel oxide
}

\author{
Suresh S. Shendage and Jayashree M. Nagarkar*
}

Department of Chemistry, Institute of Chemical Technology, Matunga (E), Mumbai - 400 019, India

\begin{tabular}{l}
\hline C H R O N I C L E \\
\hline Article history: \\
Received January 26, 2013 \\
Received in Revised form \\
May 10, 2013 \\
Accepted 20 May 2013 \\
Available online \\
24 May 2013 \\
\hline Keywords: \\
Ultrasound \\
$\beta$-enaminones \\
$\beta$-enamino esters \\
Heterogeneous catalysis \\
NiO
\end{tabular}
A B S T R A C T

An efficient and simple protocol of $\beta$-enaminones and $\beta$-enamino esters synthesis using nickel oxide under ultrasound sonication has been developed. Ultrasound sonication triggers the formation of enaminones under the mild reaction conditions. Nickel oxide was found to be efficient, heterogeneous, moisture stable, robust and recyclable catalyst.

\section{Introduction}

$\beta$-Enaminones and $\beta$-Enamino esters are important classes of organic compounds having multiple applications because of their adaptable dual behavior as electrophiles and nucleophiles ${ }^{1}$. Enaminones are widely used as versatile building blocks for synthesis of important heterocyclic compounds, nitrogen-containing compounds, naturally occurring alkaloids and pharmaceuticals with antiepileptic, anticonvulsant and antitumor properties ${ }^{2,3}$. Condensation of carbonyl compounds and amines mediated by acid catalysts is a simple methodology for synthesis of enamino esters. Diversified acid catalysts such as metal triflates ${ }^{4}$, perchlorates ${ }^{5}, \mathrm{InBr}^{6}, \mathrm{CoCl}_{2}{ }^{7}$, silica supported mineral acid ${ }^{8}$, $\mathrm{BF}_{3}{ }^{*} \mathrm{Et}_{2} \mathrm{O}^{9}$, silver nanoparticles ${ }^{10}$, copper nanoparticles ${ }^{11}$, gold salts ${ }^{12}$ and $\mathrm{Zn}(\mathrm{OAc})_{2}{ }^{13}$ have been used in the synthesis of $\beta$-enaminones and enamino esters. The above catalysts are either expensive or moisture sensitive or nonrecyclable or require harsh reaction conditions. Hence new protocol development with elimination of above drawbacks was the driving force for present research work. In the last few years, ultrasound irradiation has played a significant role in the development of synthetic protocols for organic reactions ${ }^{14}$, while metal oxide catalyzed organic transformations have attracted * Corresponding author.

E-mail addresses: jm.nagarkar@ictmumbai.edu.in (J. M. Nagarkar) 
considerable attention in last few decades ${ }^{15,16}$. Few reports have highlighted the catalytic activity of $\mathrm{NiO}$ in different chemical transformations ${ }^{17-19}$. Yet, a little attention has been given to the catalytic activity of $\mathrm{NiO}$ as compared to other metal oxides in organic synthesis.

Hence, exploring the new catalytic properties of $\mathrm{NiO}$ for different chemical transformations was of interest in the field of catalysis. We herein report an efficient and mild protocol for the synthesis of enaminones and enamino esters using $\mathrm{NiO}$ as a heterogeneous, moisture stable, robust and recyclable catalyst under ultrasonication.

\section{Results and Discussion}

The condensation of aniline and acetyl acetone was selected as a model reaction. The influence of various reaction parameters such as solvent, catalyst loading and time was examined (Table 1 entries, 1-15). Initially we have screened various metal oxides such as $\mathrm{Co}_{3} \mathrm{O}_{4}, \mathrm{ZnO}, \mathrm{CuO}$, and $\mathrm{NiO}$ as catalyst for the condensation reaction. $\mathrm{NiO}$ was found to be the most effective catalyst among the above metal oxides providing an excellent yield of $92 \%$ (Table 1, entries 1-4). The control experiment was carried out in the absence of catalyst. However reaction did not proceed in the absence of catalyst and sonication even after prolonged stirring (12h) (Table 1, entry 5). The reaction was also studied under sonication in the absence of catalyst, which resulted in very low product yield (Table 1, entry 6). We have also studied the effect of various solvents on the condensation reaction to find out the most suitable solvent for Sonication. However, it was observed that the reaction proceeded very well in the absence of solvent and under neat conditions (Table 1, entries 7-11). The catalyst loading was optimized by increasing the amount of $\mathrm{NiO}$ from $0.05 \mathrm{mmol}$ to $0.2 \mathrm{mmol}$ for $1 \mathrm{mmol}$ scale reaction. The yield increased with the increase in catalyst loading (Table 1, entries 12-15). Nevertheless, there was a very marginal increase in the yield when the catalyst loading is increased to $0.2 \mathrm{mmol}$ (Table 1, entries, 14 and 15). Hence $0.15 \mathrm{mmol}$ of catalyst was chosen as an optimal amount. Thus, the optimized reaction conditions for $1 \mathrm{mmol}$ enaminones synthesis were as follows: catalyst-NiO, catalyst loading - $0.15 \mathrm{mmol}$, time - 20 minutes and solvent free condition.

Table 1 Optimization of reaction conditions.

\begin{tabular}{|c|c|c|c|c|}
\hline \multicolumn{5}{|c|}{ Effect of catalyst } \\
\hline Entry & Solvents & Catalyst & Catalyst loading, mmole & Yield, \% \\
\hline 1 & none & $\mathrm{NiO}$ & 0.2 & 92 \\
\hline 2 & none & $\mathrm{CuO}$ & 0.2 & 60 \\
\hline 3 & none & $\mathrm{ZnO}$ & 0.2 & 50 \\
\hline 4 & none & $\mathrm{Co}_{3} \mathrm{O}_{4}$ & 0.2 & trace \\
\hline 5 & none & none & none & No reaction $^{\mathrm{a}}$ \\
\hline 6 & none & none & none & trace \\
\hline \multicolumn{5}{|c|}{ Effect of solvent } \\
\hline 7 & Methanol & $\mathrm{NiO}$ & 0.2 & 20 \\
\hline 8 & Water & $\mathrm{NiO}$ & 0.2 & trace \\
\hline 9 & Ethyl acetate & $\mathrm{NiO}$ & 0.2 & trace \\
\hline 10 & Toluene & $\mathrm{NiO}$ & 0.2 & 10 \\
\hline 11 & none & $\mathrm{NiO}$ & 0.2 & 92 \\
\hline \multicolumn{5}{|c|}{ Effect of catalyst loading } \\
\hline 12 & none & $\mathrm{NiO}$ & 0.05 & 68 \\
\hline 13 & none & $\mathrm{NiO}$ & 0.1 & 78 \\
\hline 14 & none & $\mathrm{NiO}$ & 0.15 & 90 \\
\hline 15 & none & $\mathrm{NiO}$ & 0.2 & 92 \\
\hline
\end{tabular}

Conditions: acetyl acetone $(1.2 \mathrm{mmole})$, aniline $(1 \mathrm{mmole}), 30^{\circ} \mathrm{C}$, sonication 20 min. ${ }^{a}$ Without sonication. 
In order to investigate the general applicability of protocol, various dicarbonyl and amines were condensed to give respective enaminones. The desired products were obtained in excellent yields (Table 2, entries 1-8). Aromatic amines containing electron withdrawing group such as nitro and chloro groups having strong deactivating effect were converted into corresponding products in lower yield (Table 2, entries 2 and 3). It also indicates that the catalyst shows good activity in case of liquid and semisolid compounds. However substituted aromatic amine having electron donating substituent were more reactive and afforded better yield of the corresponding product (Table 2, entries 1, and 47). The condensation of amines with different dicarbonyl compounds such as ethyl acetoacetate, methyl acetoactetate and benzoylacetone was also studied (Table 2, entries 5-8). Methyl and ethyl acetoacetate produced excellent yield of desired products (Table 2, entries 5-7). Benzoylacetone (more bulky diketone) also reacted efficiently with butyl amine to deliver a product with $90 \%$ yield (Table 2, entry 8).

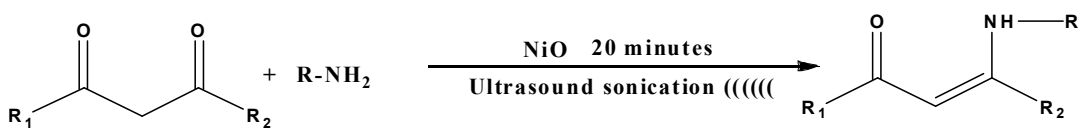

Scheme 1. Condensation of di-carbonyl compounds with amines under sonication.

Table 2. Condensation of dicarbonyl compounds with amine.

\begin{tabular}{|c|c|c|c|c|c|c|c|}
\hline Entry & $\mathrm{R}_{1}$ & $\mathrm{R}_{2}$ & $\mathrm{R}$ & Product & $\begin{array}{c}\text { m. p., }{ }^{\circ} \mathrm{C} \\
\text { (lit.) }\end{array}$ & $\begin{array}{c}\text { Yield, \% } \\
\text { (lit.) }\end{array}$ & Ref. \\
\hline 1 & $\mathrm{CH}_{3}$ & $\mathrm{CH}_{3}$ & $\mathrm{Ph}$ & & $\begin{array}{c}46-48 \\
(45-47)\end{array}$ & $\begin{array}{c}90 \\
(89)\end{array}$ & 20 \\
\hline 2 & $\mathrm{CH}_{3}$ & $\mathrm{CH}_{3}$ & $4-\mathrm{NO}_{2} \mathrm{Ph}$ & & $\begin{array}{c}142-143 \\
(142-143)\end{array}$ & $\begin{array}{c}88 \\
(65)\end{array}$ & 6 \\
\hline 3 & $\mathrm{CH}_{3}$ & $\mathrm{CH}_{3}$ & 4-ClPh & & $\begin{array}{c}60-61 \\
(59-60)\end{array}$ & $\begin{array}{c}90 \\
(85)\end{array}$ & 20 \\
\hline 4 & $\mathrm{CH}_{3}$ & $\mathrm{CH}_{3}$ & $4-\mathrm{CH}_{3} \mathrm{Ph}$ & & $\begin{array}{c}64-65 \\
(63-65)\end{array}$ & $\begin{array}{c}94 \\
(90)\end{array}$ & 20 \\
\hline 5 & $\mathrm{CH}_{3}$ & $\mathrm{OCH}_{3}$ & $\mathrm{Ph}$ & & $\begin{array}{c}46-47 \\
(46-47)\end{array}$ & $\begin{array}{c}92 \\
(91)\end{array}$ & 6 \\
\hline 6 & $\mathrm{CH}_{3}$ & $-\mathrm{OC}_{2} \mathrm{H}_{5}$ & $4-\mathrm{OCH}_{3} \mathrm{Ph}$ & & $\begin{array}{c}43-44 \\
(43-44)\end{array}$ & $\begin{array}{c}94 \\
(93)\end{array}$ & 6 \\
\hline 7 & $\mathrm{CH}_{3}$ & $-\mathrm{OC}_{2} \mathrm{H}_{5}$ & $\mathrm{Ph}$ & & oil & $\begin{array}{c}91 \\
(87)\end{array}$ & 21 \\
\hline 8 & $\mathrm{CH}_{3}$ & $\mathrm{Ph}$ & $-\mathrm{CH}_{2}-\mathrm{CH}_{2}-\mathrm{C}_{2} \mathrm{H}_{5}$ & & oil & $\begin{array}{c}90 \\
(99)\end{array}$ & 4 \\
\hline
\end{tabular}

In order to make the protocol more economical, the recyclability of $\mathrm{NiO}$ was studied. The series of model reaction of acetyl acetone and aniline were carried out consecutively for 5 times by using recycled $\mathrm{NiO}$ catalyst under identical conditions. It was observed that reused up to three cycles catalyst allow obtaining products with marginal decrease in the yields (Table 3). During each cycle 
the $\mathrm{NiO}$ was separated by centrifugation and then used for the next run after washing with distilled water and ethanol.

Table 3. Recycle run study

\begin{tabular}{ccc}
\hline Entry & Run & Yield, \% \\
\hline 1 & $1^{\text {st }}$ & 90 \\
2 & $2^{\text {nd }}$ & 89 \\
3 & $3^{\text {rd }}$ & 88 \\
4 & $4^{\text {th }}$ & 85 \\
5 & $5^{\text {th }}$ & 82 \\
\hline
\end{tabular}

Reaction Conditions: Acetyl acetone (1.2mmol), aniline (1 $\mathrm{mmol}), \mathrm{NiO}(0.15 \mathrm{mmol})$, sonication for $20 \mathrm{~min}$ at $30^{\circ} \mathrm{C}$.

\section{Conclusions}

To conclude, we have developed a new and efficient procedure for the synthesis of $\beta$-enaminones and $\beta$ - enaminone esters catalysed by $\mathrm{NiO}$ under ultrasonication at $30{ }^{\circ} \mathrm{C}$. Eonomically affordable, easy to handle, recyclable and robust nature are the advantages of $\mathrm{NiO}$ catalyst for the synthesis of $\beta$ enaminones and $\beta$-enamino esters. The protocol offers high yield of desired product with different amines and dicarbonyl compounds under solvent free ultrasonication. The other remarkable features of this protocol are simplicity, shorter reaction time and ease of separation of catalyst which make this protocol novel convenient and effective.

\section{Acknowledgements}

The authors are thankful to UGC New Delhi, India for the award of Teachers Fellowship under Faculty improvement programme (FIP).

\section{Experimental}

\subsection{Materials and Methods}

All reagents and chemicals were procured from BDH chemicals Ltd, Mumbai, India and were used without further purifications

\subsection{General procedures}

\section{Synthesis of nickel oxide (NiO)}

$\mathrm{NiO}$ was prepared by hydrothermal synthesis as mentioned below. In typical procedure, $1 \mathrm{~g}$ nickel nitrate hexahydrate and $2 \mathrm{~g}$ urea were dissolved in $30 \mathrm{~mL}$ distilled water in a $100 \mathrm{~mL}$ round bottom flask. The mixture was refluxed for $6 \mathrm{~h}$ and allowed to cool at room temperature. The resultant blue green nickel hydroxide obtained was washed with small aliquots of water and ethanol for several times and dried at $110{ }^{\circ} \mathrm{C}$ for $12 \mathrm{~h}$. It was then further subjected to calcination at $500{ }^{\circ} \mathrm{C}$ for $5 \mathrm{~h}$ to get $\mathrm{NiO}$ powder.

\section{Synthesis of Enaminones}

In a $10 \mathrm{~mL}$ round bottom flask, dicarbonyl compound $(1.1 \mathrm{mmol})$, amine $(1 \mathrm{mmol})$ and $\mathrm{NiO}(0.15$ mmol) were added and sonicated in an ultrasonic bath $(30 \mathrm{kHz})$ for $20 \mathrm{~min}$.

Progress of the reaction was monitored by TLC and Gas chromatography. On completion of reaction, $5 \mathrm{~mL}$ of ethyl acetate were added to the reaction mixture and centrifuged at $5000 \mathrm{rpm}$ for 20 minutes 
to separate the catalyst. The supernatant was slowly decanted and used for product recovery. The $\mathrm{NiO}$ was allowed to air dry and reused for further recycle run study. The crude product was extracted with ethyl acetate $(5 \mathrm{~mL} \times 3)$ and purified using column chromatography by $\mathrm{n}$-hexane. In order to study general applicability of this protocol, different dicarbonyl and amines were condensed to give different enaminones and were characterized by using GC-MS (Shimadzu Q P 2010), ${ }^{1} \mathrm{H}$ NMR (Mercury Plus $300 \mathrm{MHz}$ NMR spectrometer) and IR spectroscopy (FTIR Perkin Elmer). The m.p. of the products were determined and compared with reported methods (Table 2).

\subsection{Physical and Spectral Data}

\section{Characterization of $\mathrm{NiO}$}

The formation of $\mathrm{NiO}$ was confirmed by analytical techniques using SEM-EDAX analysis (Quanta -200 at $20 \mathrm{Kv}$ as an operating voltage) and XRD (Rigaku Miniflex model by using $\mathrm{CuK} \alpha=1.54 \AA$ with scanning range $0^{\circ}$ to $80^{\circ}$ with scanning rate 2 degree per minute).

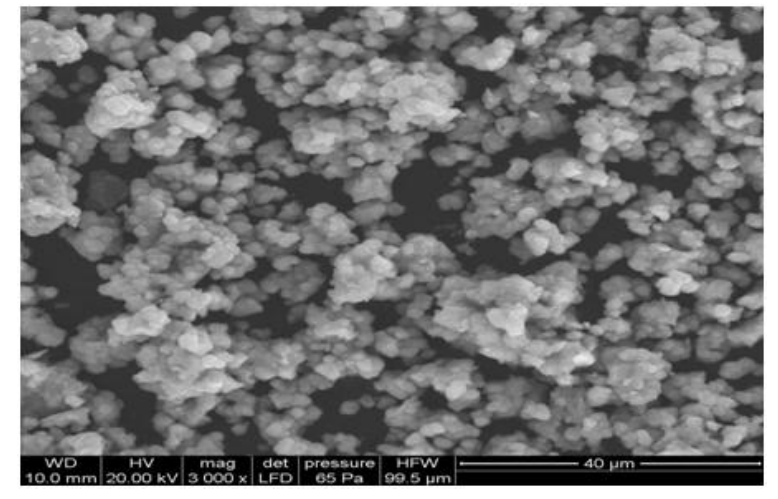

Fig. 1. SEM image of $\mathrm{NiO}$

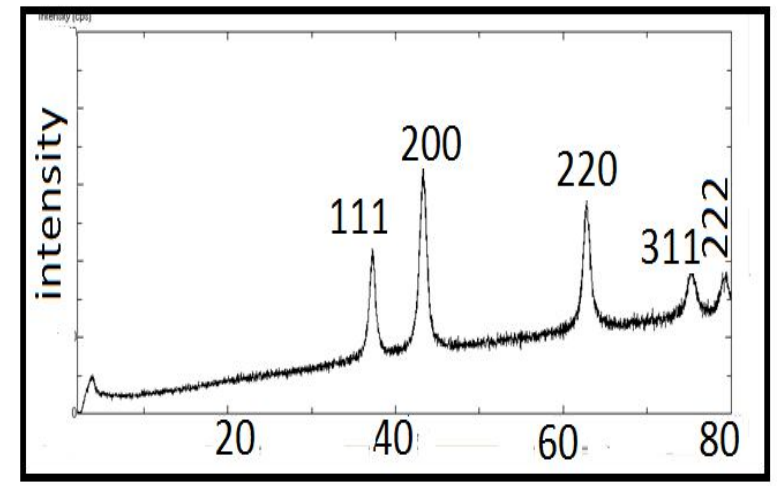

Fig. 2. XRD pattern of synthesized $\mathrm{NiO}$

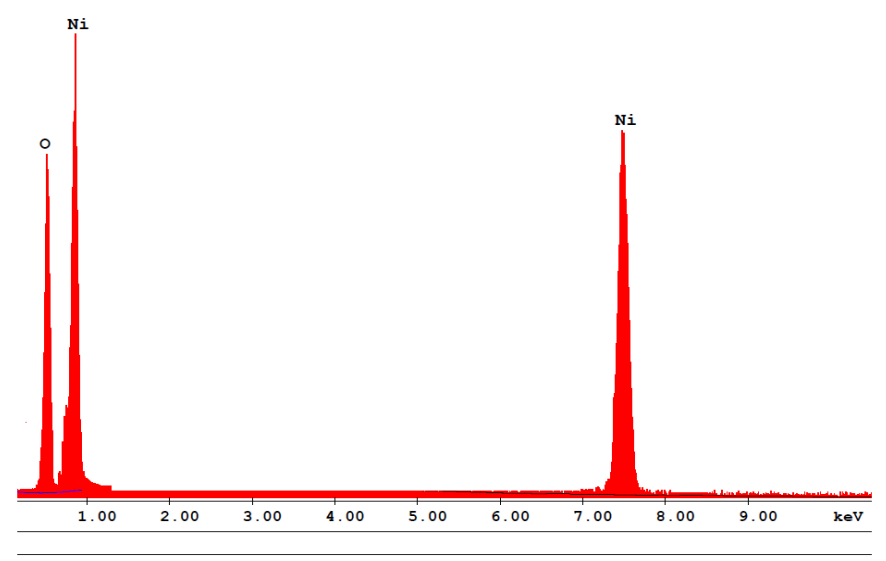

Fig. 3. EDAX analysis of $\mathrm{NiO}$

SEM image of $\mathrm{NiO}$ showed that Particles were nearly of spherical shape (Fig. 1). X-ray diffractogram of $\mathrm{NiO}$ indicates that particles exhibit good crystallanity and FCC crystal pattern with peaks at $37^{\circ}, 43^{\circ}, 63^{\circ}, 75^{\circ}$, and $79^{\circ}$ indices for (111), (200), (220), (311), (222) planes respectively (Fig. 2). The EDAX spectrum (Fig. 3) showed peaks correspond to nickel and oxygen only which confirmed purity of nickel oxide. 
Spectral data of compounds

4-(Phenylamino)pent-3-en-2-one (Table 2, entry 1). Pale yellow solid IR (KBr): $v=3400,3000$, 1580, $1600 \mathrm{~cm}^{-1} .{ }^{1} \mathrm{HNMR}\left(\mathrm{CDCl}_{3}, 300 \mathrm{MHz}\right): \delta=1.99$ (s, 3H), 2.10 (s, 3H), 5.19 (s, 1H), 7.09-7.21 (m, 3H), 7.31-7.37 (m, 2H), 12.49 (br s, $1 \mathrm{H}, \mathrm{NH}) . \mathrm{M} / \mathrm{z}$ : $174.78 . \mathrm{mp} 46-47^{\circ} \mathrm{C}$ (lit. $\left.45-47^{\circ} \mathrm{C}\right)$.

4-(4-nitrophenylamino)pent-3-en-2-one (Table 2, entry 2). Yellow solid IR (KBr): $v=3410,3090$, 2972, 1639, $1581 \mathrm{~cm}^{-1} .{ }^{1} \mathrm{HNMR}\left(\mathrm{CDCl}_{3}, 300 \mathrm{MHz}\right): \delta=2.07(\mathrm{~s}, 3 \mathrm{H}), 2.2(\mathrm{~s}, 3 \mathrm{H}), 5.23(\mathrm{~s}, 1 \mathrm{H}), 7.2(\mathrm{~d}$, $J=9.0 \mathrm{~Hz}, 2 \mathrm{H}), 7.93$ (d, $J=9.0 \mathrm{~Hz}, 2 \mathrm{H}), 12.68$ (br s, $1 \mathrm{H}, \mathrm{NH}) . \mathrm{M} / \mathrm{z}: 220.10 . \mathrm{mp} 142-143.5{ }^{\circ} \mathrm{C}$ (lit.142-143 $\left.{ }^{\circ} \mathrm{C}\right)$.

4-(4-Chlorophenylamino)pent-3-en-2-one (Table 2, entry 3). Pale yellow solid IR (KBr): $v=3466$, 3032, 1643, $1560 \mathrm{~cm}^{-1} .{ }^{1} \mathrm{HNMR}\left(\mathrm{CDCl}_{3}, 300 \mathrm{MHz}\right): \delta=2.01(\mathrm{~s}, 3 \mathrm{H}), 2.13(\mathrm{~s}, 3 \mathrm{H}), 4.98(\mathrm{~s}, 1 \mathrm{H}), 7.05$ (d, $J=8.6 \mathrm{~Hz}, 2 \mathrm{H}), 7.208$ (d, $J=8.6 \mathrm{~Hz}, 2 \mathrm{H}), 12.43$ (br s, $1 \mathrm{H}, \mathrm{NH}) . \mathrm{M} / \mathrm{z}: 209.07 . \mathrm{mp} 60-61{ }^{\circ} \mathrm{C}$ (lit. $\left.59-60{ }^{\circ} \mathrm{C}\right)$.

4-(p-Tolylamino)pent-3-en-2-one (Table 2, entry 4). Pale yellow solid IR (KBr): $v=3424,3036$, 1600, 1555, $1529 \mathrm{~cm}^{-1} .{ }^{1} \mathrm{HNMR}\left(\mathrm{CDCl}_{3}, 300 \mathrm{MHz}\right): \delta=1.99(\mathrm{~s}, 3 \mathrm{H}), 2.10(\mathrm{~s}, 3 \mathrm{H}), 2.34(\mathrm{~s}, 3 \mathrm{H}), 5.2$ (s, 1H), 7.0 (d, $J=8.7 \mathrm{~Hz}, 2 \mathrm{H}), 7.24$ (d, $J=8.7 \mathrm{~Hz}, 2 \mathrm{H}), 12.40$ (br s, 1H, NH). M/z: 189.11. mp 64$65^{\circ} \mathrm{C}$ (lit. $\left.63-65^{\circ} \mathrm{C}\right)$.

Methyl 3-(phenylamino)but-2-enoate (Table 2, entry 5). Pale yellow solid IR (KBr): $v=3257$, 2982, 1641, 1576, $1493 \mathrm{~cm}^{-1} .{ }^{1} \mathrm{H}$ NMR $\left(\mathrm{CDCl}_{3}, 300 \mathrm{MHz}\right): \delta=1.98(\mathrm{~s}, 3 \mathrm{H}), 3.78(\mathrm{~s}, 3 \mathrm{H}), 4.59$ (s, 1H), 7.18 (m, 3H), 7.20-7.30 (m, 2H), 10.46 (br s, $1 \mathrm{H}, \mathrm{NH}) . \mathrm{M} / \mathrm{z}: 191.10 . \mathrm{mp} 46-47{ }^{\circ} \mathrm{C}$ (lit. $46-47$ $\left.{ }^{\circ} \mathrm{C}\right)$.

Ethyl 3-(4-methoxyphenylamino)but-2-enoate (Table 2, entry 6). Pale yellow solid IR (KBr): $v=$ 3246, 2835, 1710, 1640, $1619 \mathrm{~cm}^{-1} .{ }^{1} \mathrm{H}$ NMR $\left(\mathrm{CDCl}_{3}, 300 \mathrm{MHz}\right): \delta=1.30(\mathrm{t}, J=6.8 \mathrm{~Hz}, 3 \mathrm{H}), 1.90$ $(\mathrm{s}, 3 \mathrm{H}), 3.82(\mathrm{~s}, 3 \mathrm{H}), 4.15(\mathrm{q}, J=6.8 \mathrm{~Hz}, 2 \mathrm{H}), 4.63(\mathrm{~s}, 1 \mathrm{H}), 6.75(\mathrm{~d}, J=8.7 \mathrm{~Hz}, 2 \mathrm{H}), 7.02(\mathrm{~d}, J=8.7$ $\mathrm{Hz}, 2 \mathrm{H}), 10.18$ (br s, $1 \mathrm{H}, \mathrm{NH}) . \mathrm{M} / \mathrm{z}$ : 235.12. mp $43-44{ }^{\circ} \mathrm{C}$ (lit. $43-44{ }^{\circ} \mathrm{C}$ ).

Ethyl 3-(phenylamino)but-2-enoate (Table 2, entry 7). Yellowish oil IR (KBr): $v=3266,2978$, $1663,1586 \mathrm{~cm}^{-1} .{ }^{1} \mathrm{H}$ NMR $\left(\mathrm{CDCl}_{3}, 300 \mathrm{MHz}\right): \delta=1.32(\mathrm{t}, J=7.3 \mathrm{~Hz}, 3 \mathrm{H}), 2.00(\mathrm{~s}, 3 \mathrm{H}), 4.20(\mathrm{q}, J=$ $7.3 \mathrm{~Hz}, 2 \mathrm{H}), 4.69$ (s, 1H), 7.17 (m, 3H), 7.30 (m, 2H), 10.48 (br s, 1H, NH). M/z: 205.16.

3-(butylamino)-1-phenylbut-2-en-1-one (Table 2, entry 8). Yellow oil IR (KBr): $v=3420,3025$, 1590, 1550, $1520 \mathrm{~cm}^{-1} .{ }^{1} \mathrm{H}$ NMR $\left(\mathrm{CDCl}_{3}, 300 \mathrm{MHz}\right): \delta=1.0(\mathrm{t}, 3 \mathrm{H}), 1.31(\mathrm{~m}, 2 \mathrm{H}), 1.52(\mathrm{~m}, 2 \mathrm{H}), 2.89$ (t, 2H), $2.26(\mathrm{~s} \mathrm{3H}), 6.95(\mathrm{~S} \mathrm{1H}), 7.89$ (d, $J=8.7 \mathrm{~Hz}, 2 \mathrm{H}), 7.60-7.73$ (d, 3H), 12.0 (br s, 1H, NH). $\mathrm{M} / \mathrm{z}: 217.10$

\section{References}

1 Elassar A., and El-Khair A. (2003) Recent developments in the chemistry of enaminones. Tetrahedron, 59, 8463-8480. 
2 Li G., Watson K., Buckheit R. W., Zhang Y. (2007) Total synthesis of Anibamine, a novel natural product as a chemokine receptor CCR5 antagonist. Org. Lett., 9, 2043-2046.

3 White D., Ihle D. (2006) Tandem photocycloaddition-retro-Mannich fragmentation of enaminones. A route to spiropyrrolines and the tetracyclic core of koumine. Org. Lett., 8, 10811084.

4 Epifano F., Genoveseb S., Curinib M. (2007) Ytterbium triflate catalyzed synthesis of $\beta$ enaminones. Tetrahedron Lett., 48, 2717-2720.

5 Das B., Venkateswrlu K., Majhi A., Reddy M., Reddy K., Rao Y., Ravikumar K. and Sridhar B. (2006) Highly efficient, mild and chemo- and stereoselective synthesis of enaminones and enamino esters using silica supported perchloric acid under solvent-free conditions. J. Mol. Catal., 246, 276-281.

6 Zhang Z., Yin L., Wang Y. (2006) A general and efficient method for the preparation of $\beta$-enamino ketones and esters catalyzed by indium tribromide. Adv. Synth. and Catal., 348, 184-190.

7 Zang Z., Hu J. (2006) Cobalt(II) chloride-mediated synthesis of $\beta$-enamino compounds under solvent-free conditions. J. Braz. Chem. Soc., 17, 1447-1451.

8 Datta B., Pasha M. (2011) Silica sulfuric acid-mediated synthesis of $\beta$-enaminones and $\beta$ enaminoesters under microwave irradiation. Phosphorus, Sulfur, and Silicon, 186, 171-177.

9 Stefane B., Polanc S. (2004) A new regio- and chemoselective approach to $\beta$-keto amides and $\beta$ enamino carboxamides via 1,3,2-dioxaborinanes. Synlett, 04, 698-702.

10 Bhatte K., Tambade P., Dhake K., Bhanage B. (2010) Silver nanoparticles as an efficient, eterogeneous and recyclable catalyst for synthesis of $\beta$-enaminones. Catal. Commun., 11, 12331237.

11 Kidwai M., Bhardwaj S., Mishra N., Bansal V., kumar A., Mozumdar S.(2009) A novel method for the synthesis of $\beta$-enaminones using Cu-nanoparticles as catalyst Catal. Commun., 10, 15141517.

12 Arcadi A., Blanchi G., Giuseppe S., Marinelli F. (2003) Gold catalysis in the reactions of 1, 3dicarbonyls with nucleophiles. Green Chemistry, 5, 64-67.

13 Vohra R., Renaud J., Bruneau C. (2005) Efficient synthesis of $\beta$-aminoacrylates and $\beta$ enaminones catalyzed by $\mathrm{Zn}(\mathrm{OAc})_{2} \cdot 2 \mathrm{H}_{2} \mathrm{O}$. Collect. Czech. Chem. Commun., 70, 1943-1952.

14 Mason T., Lorimer J. (2002) Applied sonochemistry, The Uses of Power Ultrasound in Chemistry and Processing, Wiley VCH, Verlag Gmbh.

15 Bhatte K., Sawant D., Deshmukh K., Bhanage B. (2011) Nanosize $\mathrm{Co}_{3} \mathrm{O}_{4}$ as a novel, robust, efficient and recyclable catalyst for $\mathrm{A}_{3}$-coupling reaction of propargylamines. Catal. Commun. 6 , 114-119.

16 Shreedhar B., Kumar A., Reddy P. (2010) Magnetically separable $\mathrm{Fe}_{3} \mathrm{O}_{4}$ nanoparticles: an efficient catalyst for the synthesis of propargylamines. Tetrahedron Lett., 51, 1891-1895.

17 Lal T., Liu J., Yong K., Wang C. (2008) Microwave-enhanced catalytic degradation of 4 chlorophenolover nickel oxides under low temperature. J. Hazard. Mater., 157, 496-502.

18 He H., Yang S., Yu K., Ju Y., Sun C., Wang L. (2010) Microwave induced catalytic degradation of crystal violet in nano- nickel dioxide suspensions. J. Hazard. Mater. 173, 393-400.

19 El-Safty S., Kiyozumi Y., Hanaoka T., and Mizukami F. (2008) Nanosized NiO particles wrapped into uniformly mesocaged silica frameworks as effective catalysts of organic amines. App. Catal., 337 121-129.

20 Eshghi H., Seyedi S., Safaei E., Vakili M., Farhadipour A., Mokhtari M. (2012) Silica supported $\mathrm{Fe}\left(\mathrm{HSO}_{4}\right)_{3}$ as an efficient, heterogeneous and recyclable catalyst for synthesis of $\beta$-enaminones 
and $\beta$-enamino esters, J. Mol. Catal. A: Chem., 363, 430- 436.

21 Narsaiah A., Reddy A., Reddy B and Yadav J. (2011) Amberlyst-15 ${ }^{\circledR}$ : An efficient, cost-effective and recyclable heterogeneous solid acid catalyst for the synthesis of $\beta$-enaminones and $\beta$-enamino esters. The Open Catalysis Journal, 4, 43-46. 